学術論文

\title{
永久磁石型電流重畳可変磁束モ一夕の性能評価
}

\section{Performance Evaluation of a Current Superimposition Variable Flux Machine Using Permanent Magnets}

\author{
小原 章*1 (学生員), 平田 勝弘 ${ }^{* 1}$ (正員), 新口 昇 ${ }^{* 1}$ (正員), 大野 勇輝 ${ }^{* 1}$
}

Akira KOHARA (Stu. Mem.), Katsuhiro HIRATA (Mem.), Noboru NIGUCHI (Mem.), Yuki OHNO

A current superimposition variable flux machine using permanent magnets that can control its torque constant has been proposed. This machine aims to improve the efficiency of the current superimposition variable flux reluctance machine by using permanent magnets. In this paper, the computed characteristics by carrying out measurements on a prototype are verified. The structure and operational principle of this machine are described. First, the cogging torque and EMF are measured. Finally, the N-T characteristics are measured under vector control.

Keywords: variable flux reluctance motor, magnetic harmonics, superimposed current, permanent magnet.

\section{1 緒言}

近年，電気自動車やハイブリッド自動車の普及とと もに，高性能な走行用モータの需要が高まっている。 これらの自動車の走行用モータには, 広い回転速度域 で高出力かつ高効率な特性が求められる。そのような 要求を満たすため, 様々なモータが研究・開発されて いる $[1,2]$ 。現在, 走行用モータとしては永久磁石式モ 一タが主流であり, 埋め込み磁石構造と弱め界磁制御 の組み合わせでワイドパワーバンド化を図っているが, $\mathrm{d}$ 軸電流を用いるために効率が低下するという問題が ある。

この問題を解決するために，近年では，ワイドパワ 一バンド特性を満たすモータとして, 可変磁束リラク タンスモータの研究が国内外で盛んに行われている [3-5]。可変磁束リラクタンスモータは, 回転磁界を発 生させる電機子巻線と, 界磁磁界を発生させる界磁巻 線を持つ。界磁巻線に直流電流を印加することで発生 する起磁力と, ロータの突極によるパーミアンス分布 により高調波磁束が発生し，その高調波磁束に電機子 巻線が作る回転磁界を同期させることによって動作す る。このモータは界磁電圧を制御することによって, 界磁磁界の強度を制御し, 出力特性を制御することが できる。可変磁束リラクタンスモータに関しては，2 つの巻線の配置が特性に影響が報告されている[6]ほ か，永久磁石を用いた出力特性向上手法などが提案さ

連絡先：小原 章, 广565-0871 大阪府吹田市山田丘 2-1, 大阪大学大学院工学研究科知能・機能創成工学専攻, e-mail: akira.kohara@ams.eng.osaka-u.ac.jp *1 大阪大学
れている[7]。しかし，2 種類のコイルが必要になるた め, コイルの巻線占積率が低下し, 各コイルの干渉を 回避するためにコイルエンドが肥大化する他，両コイ ルの結線が複雑であり, 生産性の低下が避けられない。 以上の理由から, 可変磁束リラクタンスモータには多 くの課題が残っている。

これらの課題を解決するため, 我々はこれまでに, Fig. 1 に示すような界磁巻線を持たない可変磁束リラ クタンスモータ（電流重畳可変磁束モータ: CSVFRM) を提案してきた[8-10]。このモータは, 界磁電圧と電機 子電圧を重畳することで, 電機子巻線のみによって駆 動することが可能である。しかし，界磁電流はトルク を発生させず，銅損の増加により効率を低下させると いう問題がある。このような課題を解決するため, 我々 はこれまでに，永久磁石を用いた永久磁石型電流重畳 可変磁束モータ(PMCSVFM)を提案し，その特性を明

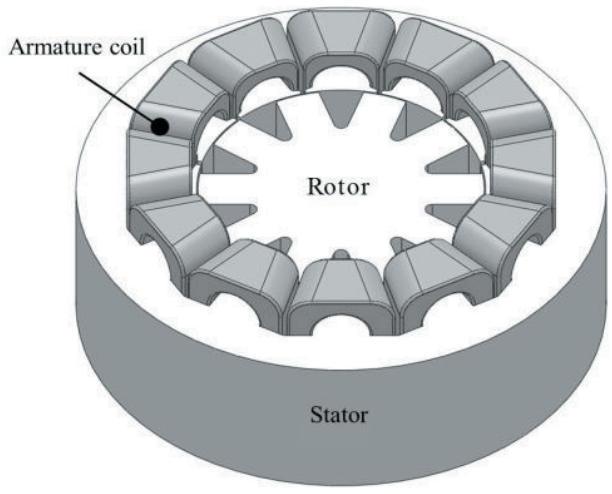

Fig. 1 Current superimposition variable flux machine without DC-coils. 


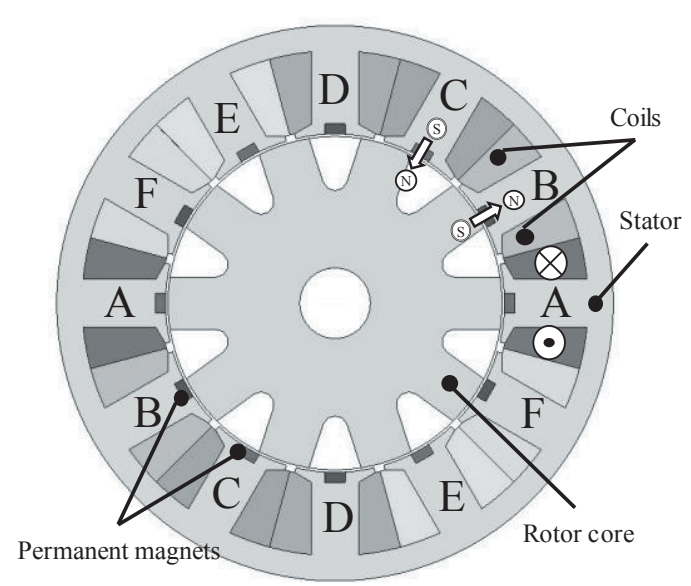

Fig. 2 Current superimposition variable flux machine using permanent magnets.

らかにしてきた[11,12]。本稿では，これまでの解析結 果の妥当性を検証するため, 試作機を用いた性能評価 を行ったので報告する。

\section{2 永久磁石型電流重畳可変磁束モ一夕}

\section{1 構造}

提案する PMCSVFM の構造を Fig. 2 に示す。ステー 夕は 12 スロット, ロータは 10 極の構成で, ロータは CSVFRM と同様に, 電磁鋼板で構成される。ステータ には電機子巻線と, 永久磁石を有する構造となってい る。電機子巻線は U, V, W の三相で構成されており, $\mathrm{U}, \mathrm{V}, \mathrm{W}$ のペアが 4 個存在する。永久磁石は矢印の 方向に磁化されており, 界磁電流によって発生する界 磁磁束と順方向に磁束が発生するように配置されてい る。電機子巻線の $U, V, W$ の三相を 2 つのペアに分 け，一方を A， B， C 相，他方を $\mathrm{D} ， \mathrm{E} ， \mathrm{~F}$ 相とする。 ステータのコイルは任意のスロットを基準として, A, B， C， D， E，F相の順に巻かれている。

\section{2 駆動方法}

$\mathrm{A} ， \mathrm{~B} ， \mathrm{C}$ 相および D， E， F 相に通常の三相交流電 流が流れるように電圧 $\left(V_{u}, V_{v}, V_{w}\right)$ を印加するとと もに, 界磁電圧として Fig. 3 のように A 相, C 相, E 相には+ $V$ の直流電圧, $\mathrm{B}$ 相, $\mathrm{D}$ 相, $\mathrm{F}$ 相には $-V$ の直 流電圧を重畳する。このとき相電流は, 通常の三相交 流に直流の界磁電流が加わった波形となる。つまり, 界磁電流と永久磁石による起磁力と, ロータの突極に よるパーミアンス分布により高調波磁束が発生し, そ れと通常の三相交流による回転磁界が同期してモータ は駆動力を得る。

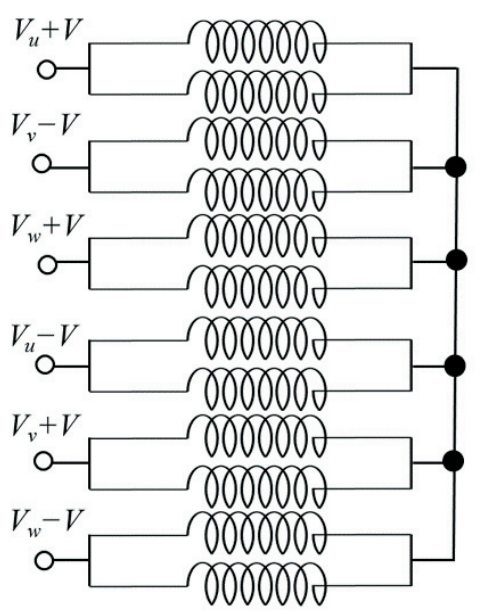

Fig. 3 Applied voltage on each coil.

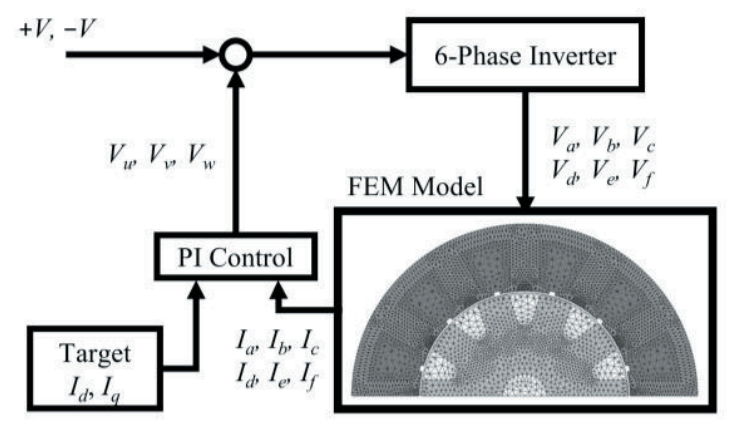

Fig. 4 Control model.

モータ制御モデルを Fig. 4 に示す。本モータは 6 相 の交流電流によって駆動するが，このとき，U 相に相 当する $\mathrm{A}$ 相, $\mathrm{D}$ 相の電流, $\mathrm{V}$ 相に相当する $\mathrm{B}$ 相, $\mathrm{E}$ 相 の電流, $\mathrm{W}$ 相に相当する $\mathrm{C}$ 相, $\mathrm{F}$ 相の電流をそれぞれ 足し合わせることによって，仮想的な 3 相交流電流が 得られる。この仮想電流に対してベクトル制御を適用 することで，モータ制御を行う。ここで，ベクトル制 御における d, q 軸は, それぞれ 4 次の高調波磁束の振 幅が最大となる方向を $\mathrm{d}$ 軸, ゼロとなる方向を $\mathrm{q}$ 軸と 定義する。

\section{3 動作原理}

ここでは, 数式を用いて PMCSVFM の動作原理を述 べる。ロータの突極数を $N_{r}$, 界磁電流と永久磁石によ ってステータ内側に発生する磁束密度の次数を $N_{f}$, 電 機子巻線に三相交流を印加したときに発生する磁束密 度の次数を $N_{a}$ とする。まず, 界磁電流と永久磁石によ って生じる起磁力の基本波 $F_{f}$ と, ロータのパーミアン ス分布の基本波 $P_{f}$ はそれぞれ式(1), 式(2)のように表す ことができる。 


$$
\begin{gathered}
F_{f}=F_{0} \sin N_{f} \theta \\
P_{f}=P_{0}+P_{1} \sin N_{r}\left(\theta+\theta_{r}\right)
\end{gathered}
$$

ここで, $F_{0}$ は起磁力の振幅, $P_{0}$ はパーミアンスの振幅, $P_{1}$ はパーミアンスの平均值, $\theta$ は回転方向位置, $\theta_{r}$ は 任意の回転方向位置扔らのロータの回転角度を表す。 エアギャップ中の磁束 $\Phi_{f}$ は起磁力とパーミアンスの 積で表すことができ，式(3)が得られる。

$$
\begin{aligned}
\Phi_{f} & =F_{0} P_{0} \sin N_{f} \theta \\
+ & \frac{1}{2} F_{0} P_{1}\left[\begin{array}{l}
\cos \left\{\left(N_{r}-N_{f}\right) \theta+N_{r} \theta_{r}\right\} \\
-\cos \left\{\left(N_{r}+N_{f}\right) \theta+N_{r} \theta_{r}\right\}
\end{array}\right]
\end{aligned}
$$

エアギャップ中の磁束 $\Phi_{f}$ と三相交流による回転磁界 の磁束 $\Phi_{a}$ の次数 $N_{a}$ が等しい場合, 両者がカップリン

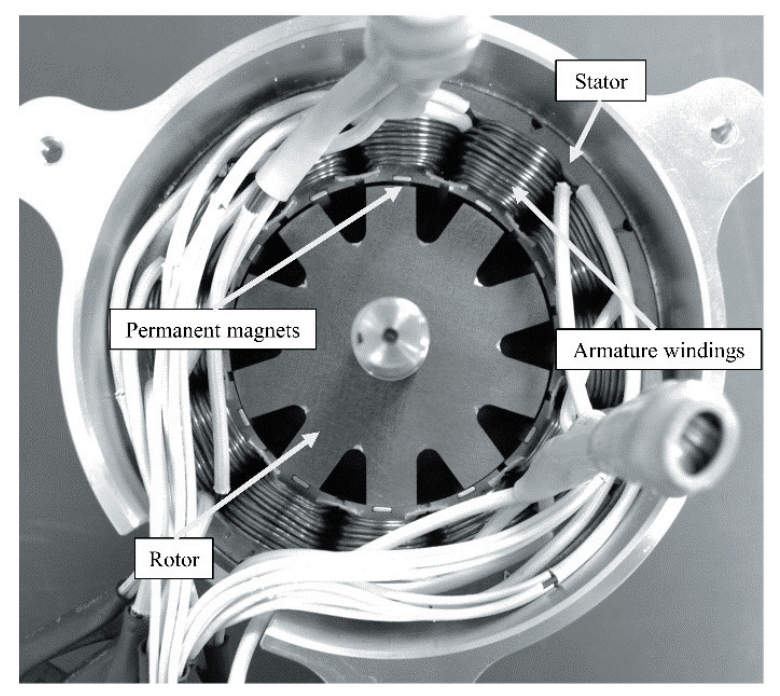

Fig. 5 Prototype.

Table 1 Specifications of the motor.

\begin{tabular}{|l|c|}
\hline Stator outer diameter $(\mathrm{mm})$ & 110 \\
\hline Stator inner diameter $(\mathrm{mm})$ & 67 \\
\hline Rotor outer diameter $(\mathrm{mm})$ & 66 \\
\hline Stack length $(\mathrm{mm})$ & 83 \\
\hline Magnetic material & $35 \mathrm{~A} 300$ \\
\hline Number of poles & 10 \\
\hline Number of slots & 12 \\
\hline Number of coil turns & 20 \\
\hline Coil resistance & $0.015 \Omega /$ Coil \\
\hline Size of permanent magnet $(\mathrm{mm})$ & $1.0 \times 4.0 \times 83.0$ \\
\hline Remanence of permanent magnet $(\mathrm{T})$ & $B r=1.3$ \\
\hline DC supply voltage $(\mathrm{V})$ & 13.8 \\
\hline
\end{tabular}

グし, 三相交流によりロータは回転する。したがって， 式(4)が成立しなければならず, 回転磁界の回転角度を $\theta_{a}$ とすると, $\theta_{a}$ と $\theta_{r}$ の関係は式(5)で表される。

$$
\begin{aligned}
& N_{a}=N_{r} \pm N_{f} \\
& N_{r} \theta_{r}=N_{a} \theta_{a}
\end{aligned}
$$

Fig. 2 の PMCSVFM では, $N_{r}=10, N_{a}=4$ なので, 任意 のスロットから反時計回りに $\mathrm{A}, \mathrm{B}, \mathrm{C}, \mathrm{D}, \mathrm{E}, \mathrm{F}$ 相と 決めることで界磁電流による磁束密度の次数は $N_{f}=6$ となり，式(4)が満たされる。

\section{3 試作機による性能評価}

\section{1 試作機と測定装置}

実験に使用した試作機を Fig. 5 に示す。また、試作 機の主な仕様を Table 1 に示す。誘起電圧およびコギン グトルクの測定実験には, Panasonic 製のサーボモータ (MSMD082G31N) を用いており，Fig. 6 に示す測定

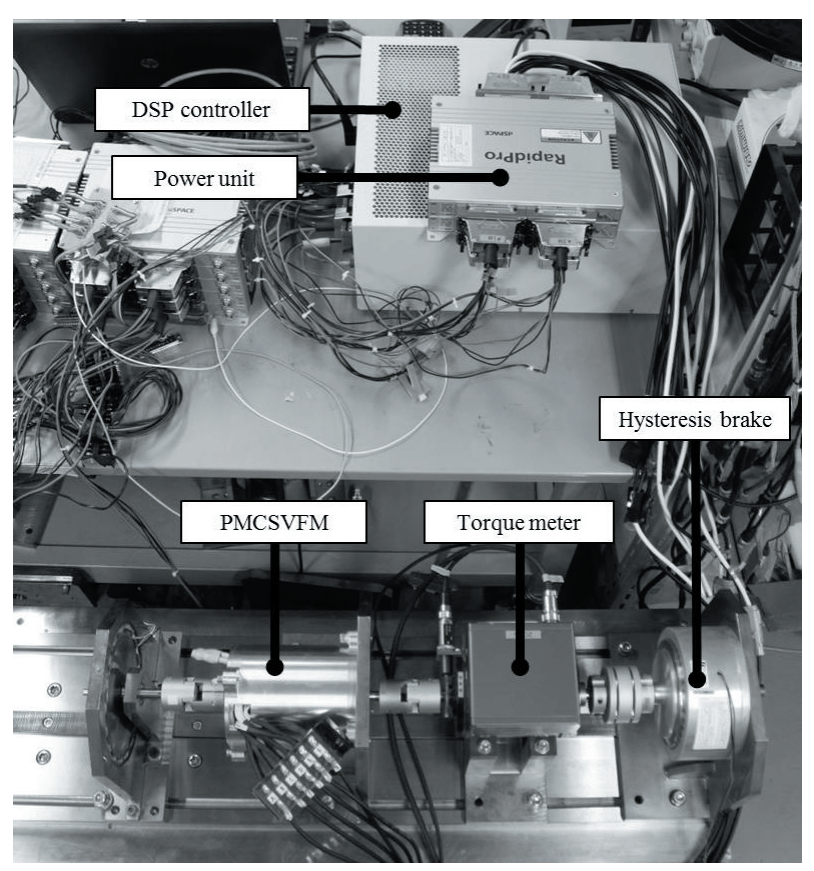

Fig. 6 Measurement system for the PMCSVFM.

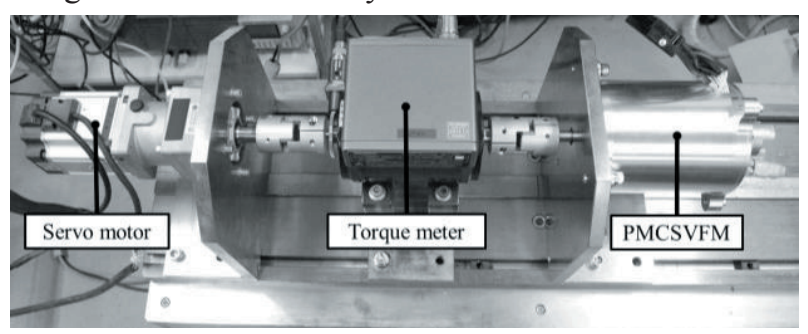

Fig. 7 Drive system for the PMCSVFM. 


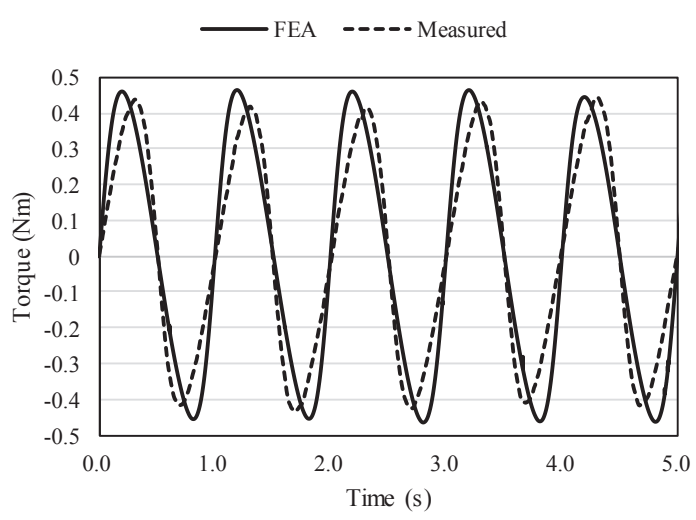

Fig. 8 Cogging torque waveform.

システムで計測を行った。モータ駆動システムを Fig. 7 に示す。モータ駆動には, dSPACE 製の DSP コントロ ーラ (DS5202), Power unit（DS1651）を用いている。 モータ負荷はマグトロール製のヒステリシスブレーキ (HB-750M-2)によって与えられ, トルク測定には小野 測器製トルク検出器（TH-1205）を用いている。

\section{2 コギングトルク波形}

コギングトルク波形を Fig. 8 に示す。この時，ロー タはサーボモータにより回転速度 $1 \mathrm{rpm}$ で駆動してお り, 界磁電流は印加していない。この図から, 解析值 と測定值のコギングトルクは，それぞれ $0.46 \mathrm{Nm}$, $0.44 \mathrm{Nm}$ 程度であり, 定量的に一致していることが確 認できる。一方, 測定值の波形は解析值の波形と異な っている。この原因は, 実験においてはトルク変動に よってサーボモータの回転速度が一定でないことが挙 げられる。ここで, PMCSVFM のコギングトルクの発 生メカニズムについて考える。ステータの6極対の永 久磁石がロータの 10 個の磁極により変調されて 4 極対 の磁束が生じるので, ロータは 4 極対の永久磁石を有 しているとみなすことができる。このとき，ロータの 8 極とステータの 12 スロットの最小公倍数の 24 次成 分ではなく, 60 次成分がコギングトルクの基本次数と なっている。これは, 式(3)の第 2 項より求まるが， 4 極対の磁束がロータの回転速度の 2.5 倍で回転するた めである。つまり, 24 次成分を 2.5 倍すると 60 次成分 になり，Fig. 8 の結果と一致することが確認できる。

\section{3 誘起電圧波形}

有限要素法解析（FEA）と実験による誘起電圧波形 をそれぞれ Fig. 9， Fig. 10 に示す。この時，ロータは サーボモータによって回転速度 200rpm で駆動してお

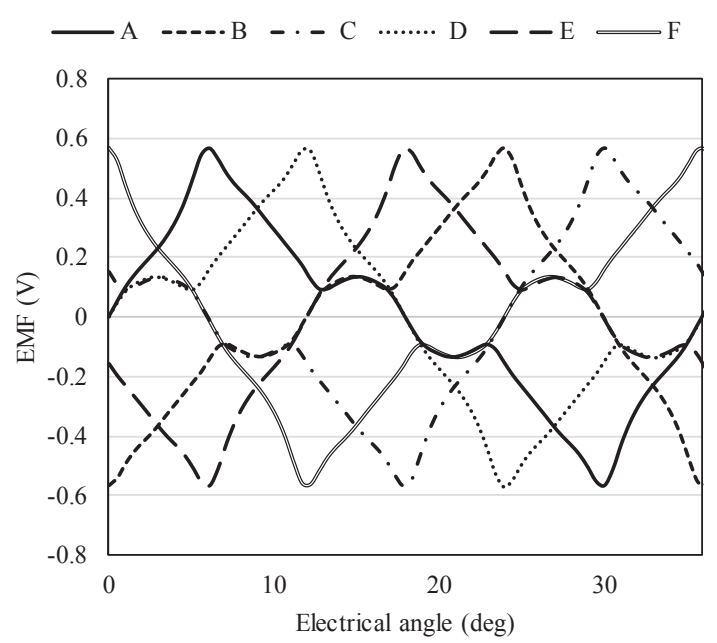

Fig. 9 EMF waveform (FEA).

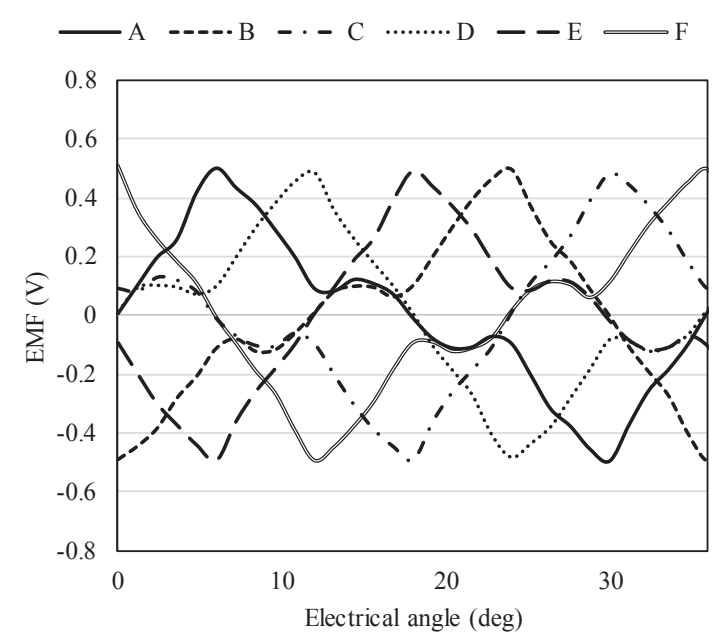

Fig. 10 EMF waveform (Measurement).

り, 界磁電流は印加していない。これらの図から, 解 析值と測定值の波形形状はよく一致していることがわ かる。また，測定值は解析值に比べピーク值が小さい が，これは公差によって永久磁石サイズが小さくなっ ており,特性が低下しているためであると考えられる。 同相（A 相および $\mathrm{D}$ 相， B 相および $\mathrm{E}$ 相，C相および F 相）で波形が一致していないが，これは，それぞれ のコイルに対向するロータの磁極の位置が異なってい るからである。

\section{4 最大トルク制御時の特性}

2 章で示した制御モデルに基づき試作機を駆動させ， 諸特性を計測した。モータ制御プログラムは任意の目 標 $\mathrm{d}$ 軸, $\mathrm{q}$ 軸電流值, 界磁電流值を設定できるよう作 成し, 最大トルク制御（ $\left.i_{d}=0\right)$ を行っている。界磁電 


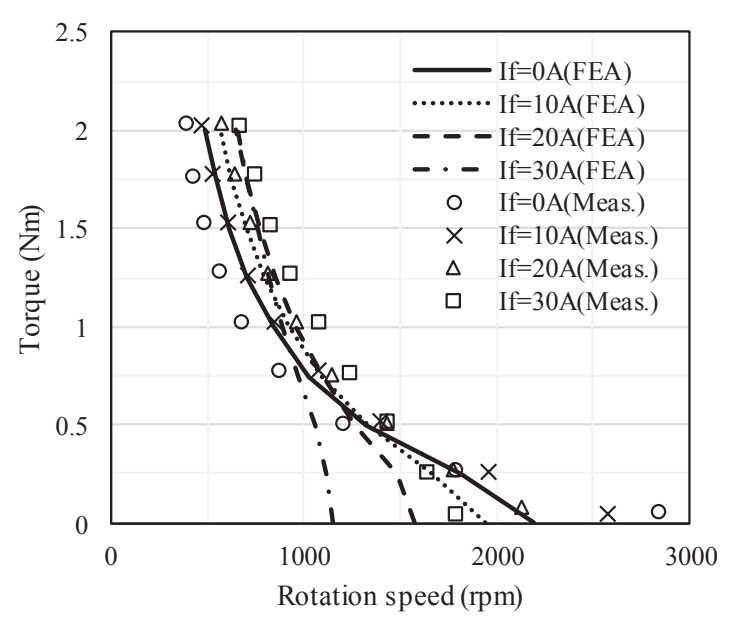

Fig. 11 N-T characteristics.

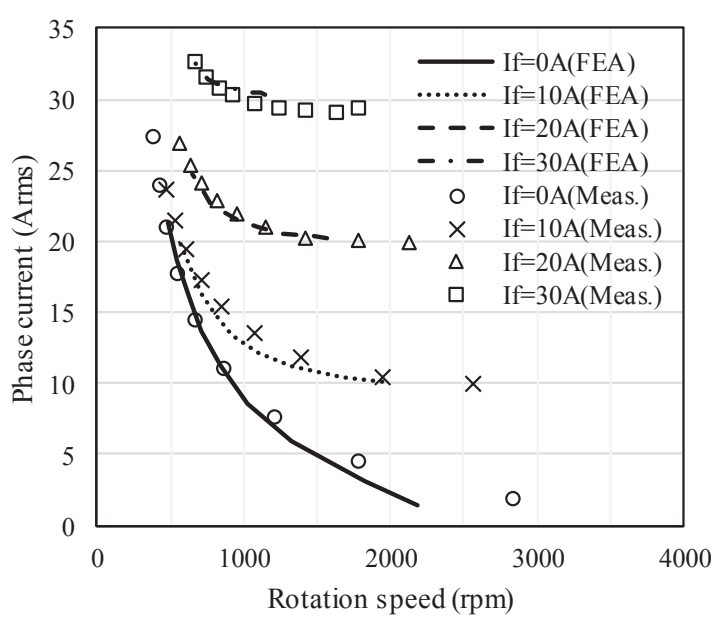

Fig. 12 N-I characteristics.

流を 0，10，20，30A の 4 通りに変化させた場合の， FEA と実験による N-T 特性を Fig. 11 に示す。界磁電 流の変化とともに出力が変化していることから, FEA と実験による結果には定性的な一致が見られ，試作機 においても可変磁束特性が得られていることがわかる。 しかし, 解析值と測定值は一致しておらず, 以下の二 つの原因が考えられる。

一つは, 3.3 節で述べたように, 永久磁石の公差によ って，特性が低下していることが挙げられる。本稿の 試作機では, モータ体格に対して磁石が小さく, マイ ナス公差による特性低下への影響が大きいことが考え らえる。

もう一つは, 本モータの駆動原理に起因していると 考えられる。本モ一タは, 界磁電流と永久磁石から発 生する界磁磁束の平衡状態を, 電機子磁束が崩すこと によって駆動する $[12,13] 。 こ の$ 時, 永久磁石による界 磁磁束と電機子磁束が対向すると, 磁束は軸方向へ漏

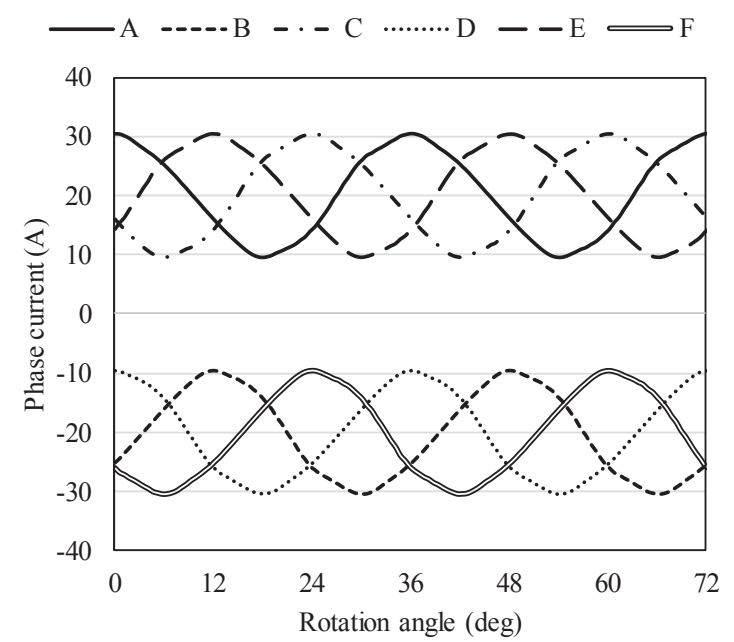

Fig. 13 Phase current waveforms (FEA).

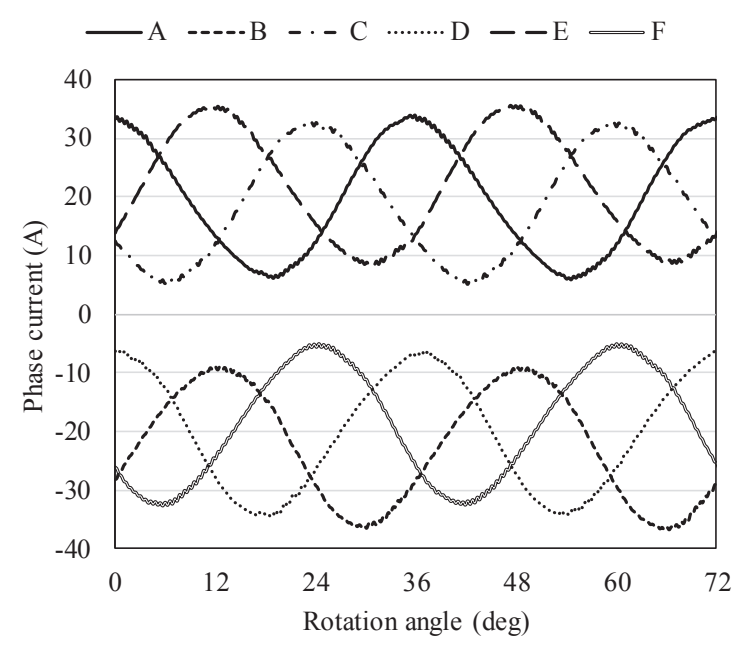

Fig. 14 Phase current waveforms (Measurement).

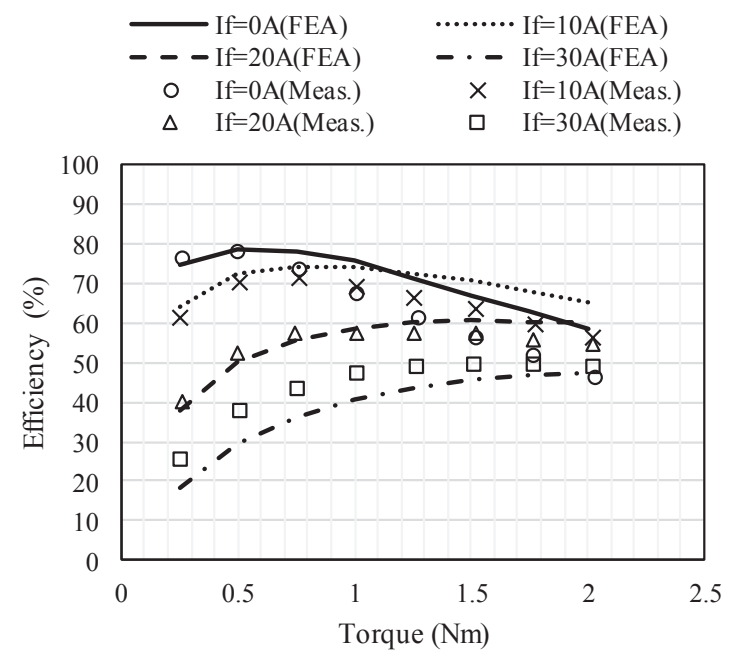

Fig. 15 Motor efficiency.

れやすくなる。その結果，トルクは低下寸るが，解析 は2 次元で行っているため, 軸方向への漏れを考慮で 
きない。したがって, 電機子電流の増加とともに, 解 析值と測定值の差が大きくなっていると考えられる。

N-I 特性を Fig. 12 に示寸。界磁電流の上昇によって, 相電流も増加していることが確認できる。低速域で解 析值と測定值の差が大きいが，これは上記の永久磁石 の特性低下, および磁束漏れによってトルク発生に必 要な電機子電流が増加していることが原因であると考 えられる。

\section{5 電流波形}

FEA と実験による界磁電流 20A, 負荷 $1 \mathrm{Nm}$ 時の相 電流波形を，それぞれ Fig. 13，Fig. 14 に示寸。3相の 電機子電流に直流の界磁電流成分が重畳された波形が 得られていることがわかる。前節でも述べた通り, 測 定值は解析值に比べ, わずかに電流值が増加している。 ここで, 各相電流の大きさが一致していない原因は, 制御装置の仕様により, 各相に同一の DC 電流を入力 することが困難だからである。

\section{4 モ一夕効率}

FEA と実験により求めた, 界磁電流を $0,10,20$, 30Aの 4 通りに変化させた場合のモータ効率を, Fig. 15 に示寸。界磁電流 $0 \mathrm{~A}$ 時には, 永久磁石の効果によっ て界磁電流を必要としないため, 比較的効率が高い。 しかし，界磁電流を増加させると銅損が支配的となる ため, 永久磁石の効果は小さく, 効率は低下している。

前述の永久磁石特性低下や磁束漏孔の影響により, 解析值と測定值は一致しないものの, 定性的な傾向は 一致していることがわかる。一部の実験值の効率が FEA と比べて高くなっている原因は, 永久磁石の特性 低下により鎖交磁束が減少し, 回転数が増加すること で, 出力が大きくなっているためである。特性が低下 した分, トルク発生に必要な電流は増加し, 損失も大 きくなるが，軽負荷域では損失の増大よりも出力増加 の影響が大きく, 結果として効率が高くなっていると 考えられる。

\section{5 結言}

本稿では, 永久磁石型電流重畳可変磁束モー夕を試 作し, FEA と実験によって運転特性評価を行った。試 作機においても，永久磁石を用いることによって，界 磁電圧を印加しなくても駆動力が発生することを確認 し, さらに界磁電圧の増減により運転特性を制御可能 であることが確認できた。しかし，永久磁石の配置や
形状が運転特性に与える影響は大きく，必ずしも永久 磁石を有効に使えているわけではないことがわかった。 また, 今回の解析では軸方向の漏孔磁束を考慮できて おらず，解析值と測定值とで差が生じた。今後は，永 久磁石の磁束の利用効率向上のために，永久磁石の配 置・形状を検討するとともに，三次元有限要素解析に より特性を比較することで，特性向上を図る。

(2016年 9 月日受付, 2016 年 5 月 12 日再受付, 2016 年 5 月 30 日再々受付)

\section{参考文献}

[1] 堺和人, 倉持暁, ハイブリッド可変磁力モータの原理と 基本特性, 電学論 D-131, No. 9, pp. 1112-1119, 2011.

[2] 佐藤隆之, 新冨将克, 瀬尾宣英, デミオ $\mathrm{EV}$ の電子式巻 線切り替えモータドライブの開発，マツダ技報, No. 30, pp. 120-124, 2012.

[3] 深見正, 山田知徳, 島和男, 津田敏宏, 川村光弘, 磁束 変調同期電動機, 電学論 D-132, No. 6, pp. 634-640, 2014

[4] Yosuke Kashitani, and Shoji Shimomura, Novel Slipring-less winding-Excited Synchronous Machine, Proc. ICEMS, pp. 1-6, 2011.

[5] X. Liu, and Z. Q. Zhu, Electromagnetic Performance of Novel Variable Flux Reluctance Machines With DC-Field Coil in Stator, IEEE Trans. Magnetics, Vol. 49, No. 6, pp. 3020-3028, 2013.

[6] 青木裕史, 深見正, 島和男, 津田敏宏, 川村光弘, 磁束 変調同期機の出力特性に及ぼす巻線取り付け位置の影響, 電学論 D-132, No. 9, pp. 922-930, 2012.

[7] 前田裕也, 小坂卓, 松井信行, 磁石配置の異なる HEFSM の発生トルク分析, 電気学会, モータドライブ 回転機 自 動車研究会資料, MD-15-87, RM-15-68,VT-15-15, pp.75-80, 2015.

[8] 新口昇, 平田勝弘, 大野勇輝, 小原章, 電流重畳可変磁 束リラクタンスモータの高出力モード, 電気学会, マグ ネティックスリニアドライブ合同研究会資料, MAG-14-217, LD-14-109, pp.79-84, 2014.

[9] 小原章, 平田勝弘, 大野勇輝, 新口昇, 電流重畳可変磁 束リラクタンスモータ, 電学論 D-135,No. 11, pp. 1077-1084, 2015.

[10] 新口昇, 平田勝弘, 大野勇輝, 小原章, 電流重畳可変磁 束リラクタンスモータのパワーバンドの検証, 電気学会, 回転機 リニアドライブ 家電・民生合同研究会資料, RM-15-077, LD-15-028,HCA-15-030, pp.33-38, 2015.

[11] 小原章, 平田勝弘, 新口昇, 大野勇輝, 永久磁石を補助 的に用いた電流重畳可変磁束モー夕, 第 23 回 MAGDA コンファレンス論文集, pp. 183-187, 2014.

[12] 小原章, 平田勝弘, 新口昇, 大野勇輝, 永久磁石補助型 電流重畳可変磁束モー夕の性能評価, 電気学会, 回転機 リニアドライブ 家電・民生合同研究会資料, RM-15-78, LD-15-29,HCA-15-31, pp.39-42, 2015. 